\title{
Regulation of Cardiomyocyte T-Tubular Structure: Opportunities for Therapy
}

\author{
Ornella Manfra $^{1} \cdot$ Michael Frisk $^{1} \cdot$ William E. Louch $^{1}$
}

Published online: 26 April 2017

(C) The Author(s) 2017. This article is an open access publication

\begin{abstract}
Purpose of Review Membrane invaginations called t-tubules play an integral role in triggering cardiomyocyte contraction, and their disruption during diseases such as heart failure critically impairs cardiac performance. In this review, we outline the growing understanding of the malleability of t-tubule structure and function, and highlight emerging t-tubule regulators which may be exploited for novel therapies.

Recent Findings New technologies are revealing the nanometer scale organization of t-tubules, and their functional junctions with the sarcoplasmic reticulum called dyads, which generate $\mathrm{Ca}^{2+}$ sparks. Recent data have indicated that the dyadic anchoring protein junctophilin-2, and the membranebending protein BIN1 are key regulators of dyadic formation and maintenance. While the underlying signals which control expression and localization of these proteins remain unclear, accumulating data support an important role of myocardial workload.

Summary Although t-tubule alterations are believed to be a key cause of heart failure, the plasticity of these structures also creates an opportunity for therapy. Promising recent data suggest that such therapies may specifically target junctophilin-2, BIN1, and/or mechanotransduction.
\end{abstract}

This article is part of the Topical Collection on Experimental Therapeutics

Ornella Manfra

ornella.manfra@medisin.uio.no

1 Institute for Experimental Medical Research, Oslo University Hospital and University of Oslo, Kirkeveien 166,

NO-0407 Oslo, Norway
Keywords T-tubules $\cdot$ Heart failure $\cdot$ Cardiomyocytes $\cdot$ Calcium homeostasis $\cdot$ Junctophilin-2 $\cdot$ Bridging integrator-1

$\begin{array}{ll}\text { Abbreviations } \\ \text { BIN1 } & \text { bridging integrator-1 } \\ \text { CICR } & \mathrm{Ca}^{2+} \text {-induced } \mathrm{Ca}^{2+} \text { release } \\ \text { DAD } & \text { delayed afterdepolarization } \\ \text { EAD } & \text { early afterdepolarization } \\ \text { EC coupling } & \text { excitation-contraction coupling } \\ \text { JPH2 } & \text { junctophilin-2 } \\ \text { LTCC } & \text { L-type } \mathrm{Ca}^{2+} \text { channel } \\ \text { RyR } & \text { ryanodine receptor } 2 \\ \text { SR } & \text { sarcoplasmic reticulum } \\ \text { NCX } & \text { sodium-calcium exchanger 1 } \\ \text { Tcap } & \text { titin cap }\end{array}$

\section{Introduction}

In mammalian cardiac myocytes, invaginations of the sarcolemmal membrane create an extensive network called the ttubule system. These structures allow the cardiac action potential to propagate into the interior of the myocyte, initiating the process of excitation-contraction (EC) coupling. This role is afforded by precise control of the structure and function of ttubules and their constituent ion transporters. Recent data have revealed an impressive malleability of t-tubules, giving new insight into how they are assembled and maintained, but also how they can be pathologically altered. In the present review, we outline these exciting new findings, and particularly highlight the emerging understanding of how t-tubule structure and function may be therapeutically targeted in diseases such as heart failure. 


\section{T-Tubule Structure}

In ventricular cardiomyocytes, t-tubules are present in a wellorganized network. The majority of tubules in these cells are oriented transversely along z-lines, leading to the original designation of this system as the "transverse" or "t"-tubule network $[1,2]$. However, closer examination revealed a surprisingly high proportion of tubules which run along the longitudinal axis of the cell, forming roughly perpendicular junctions with their transversely-oriented counterparts (Fig. 1a) [6]. In an effort to more accurately describe this bi-directional structural arrangement, the network is sometimes referred to as the transverse-axial tubule system (TATS) [7]. In ventricular cardiomyocytes, t-tubules vary in diameter (20-450 nm [6]), constituting $0.8-3.6 \%$ of the total cell volume and $21-64 \%$ of the total sarcolemma [8-11]. Species-dependent differences also exist, with a tendency toward denser and thinner structures in smaller species with higher heart rates (Fig. 1a) $[6,12$, 13].

T-tubules were long reported to be absent in atrial myocytes, and it was often hypothesized that the smaller, thinner size of these cells precluded a necessity for initiation of excitation-contraction coupling at internal sites [14]. Recent data have dispelled this belief, with numerous reports indicating the presence of t-tubules in both large and small mammalian species (Fig. 1b) [4, 5, 15-19]. However, in comparison with ventricular myocytes, the t-tubule network of atrial cells is generally less well developed, and more variable between cells. In rat, for example, we and others have observed that only approximately $1 / 3$ of atrial cells are tubulated, and when present, the arrangement of tubules is often predominantly longitudinal (Fig. 1b) [4, 20].

\section{T-Tubule Function}

While the gross morphology of t-tubules in ventricular and atrial myocytes has been described in ever increasing detail, more attention has also been given to their nanometer scale organization and function. Of key importance for EC coupling are specialized junctions between the membranes of the $\mathrm{t}$ tubules and sarcoplasmic reticulum (SR) known as dyads (Fig. 2). Within these couplings, which are located along both transverse and longitudinally-oriented t-tubules [21, 22], Ltype $\mathrm{Ca}^{2+}$ channels (LTCCs) face ryanodine receptors (RyRs) in the SR membrane, across a narrow $12-15 \mathrm{~nm}$ dyadic cleft [23]. As the action potential is propagated into the ttubules by the opening of $\mathrm{Na}^{+}$channels, this depolarization triggers LTCC opening and the resulting $\mathrm{Ca}^{2+}$ entry elicits SR $\mathrm{Ca}^{2+}$ release via the RyRs. This process, known as $\mathrm{Ca}^{2+}$-induced $\mathrm{Ca}^{2+}$ release (CICR), results in high cytosolic $\mathrm{Ca}^{2+}$ concentration and initiation of contraction as $\mathrm{Ca}^{2+}$ binds to the myofilaments. Precise positioning of LTCCs and RyRs is essential for efficient CICR. Both proteins are present in clusters [24] with an estimated stoichiometry of 4-10 RyRs per LTCC [25]. In recent years, several studies have employed super-resolution microscopy to gain further insight into the arrangement of RyRs. In rat ventricular cardiomyocytes, Baddeley et al. reported that each dyad contains an average of 14 RyRs, grouped into a number of "super-clusters" [26]. Close localization of these super-clusters allows their cooperation in the production of a $\mathrm{Ca}^{2+}$ spark, the fundamental unit of $\mathrm{Ca}^{2+}$ release in cardiomyocytes [27]. Openings of individual super-clusters, on the other hand, have been suggested to underlie smaller release events known as $\mathrm{Ca}^{2+}$ quarks [28].

During relaxation of the cell, released $\mathrm{Ca}^{2+}$ is recycled into the SR by the action of SERCA and extruded from the cell by the $\mathrm{Na}^{+}-\mathrm{Ca}^{2+}$ exchanger in the cell membrane. Like LTCCs, NCX is expressed at higher density in the t-tubules than in the surface sarcolemma, and along both transverse and longitudinal tubules $[22,29]$. Although its precise location has long been debated, there is a growing consensus that a significant fraction of NCX molecules are colocalized with RyRs, suggesting that they are located in or very near dyads (Fig. 2) [24, $30-32]$. This localization is believed to ensure rapid $\mathrm{Ca}^{2+}$ removal following a $\mathrm{Ca}^{2+}$ spark [33]. However, when functioning in so-called "reverse mode", NCX can yield $\mathrm{Ca}^{2+}$ influx which may trigger SR $\mathrm{Ca}^{2+}$ release from nearby RyRs [34-37]. Such activity is promoted by local elevation of dyadic $\mathrm{Na}^{+}$levels and, since the NCX is electrogenic, by depolarized membrane potentials.

Even in the absence of trigger $\mathrm{Ca}^{2+}$ from nearby LTCCs or $\mathrm{NCX}, \mathrm{RyR} \mathrm{Ca}^{2+}$ release can be elicited by $\mathrm{Ca}^{2+}$ diffusion from neighboring dyads. In its most dramatic form, spontaneous $\mathrm{Ca}^{2+}$ waves of CICR can be observed to propagate across entire cardiomyocytes. However, in cells with low t-tubule density, smaller wave-like patterns of $\mathrm{Ca}^{2+}$ release also occur during the action potential, as $\mathrm{Ca}^{2+}$ diffuses from intact dyads into the gaps between them where non-dyadic or "orphaned" RyRs are present [38-43] (Fig. 2). Thus, t-tubule density is an important determinant of the synchrony of $\mathrm{Ca}^{2+}$ release across the cardiomyocyte, and thus the kinetics of the rising phase of the $\mathrm{Ca}^{2+}$ transient.

\section{Malleability of T-Tubule Structure/Function during Health and Disease}

T-tubules exhibit remarkable plasticity of both their structure and function, and this has important consequences for $\mathrm{Ca}^{2+}$ homeostasis and overall cardiac function. In small rodents, ttubules are absent in neonatal cardiomyocytes and start to appear as the heart matures. This growth starts with a rudimentary, largely longitudinally-oriented network, which then evolves into a denser, primarily transversely-oriented system [44]. Interestingly, a recent study reported that sheep exhibit 
Fig. 1 T-tubule organization in ventricular and atrial cardiac myocytes. a Confocal images of the t-tubule network in tissue sections from human ventricle (top left, unpublished) and rat ventricle (top right, modified from [3]), labeled with wheat germ agglutinin (WGA) and lipophilic membrane indicator FM4-64, respectively. Threedimensional reconstructions of single cardiomyocytes from human and rat ventricle are shown in the lower panels (WGA labeling, human cell unpublished, rat cell reproduced from [4]) $\mathbf{b}$ Confocal images of the t-tubule network in tissue sections from human and pig atria (upper panels, WGA labeling; [4, 5]), and isolated rat atrial myocytes (lower panel, di-8-ANEPPS staining; [4]). Variable t-tubule organization was observed across the atria in all three species. Images from [3-5], reproduced with permissions

\section{A Ventricle}
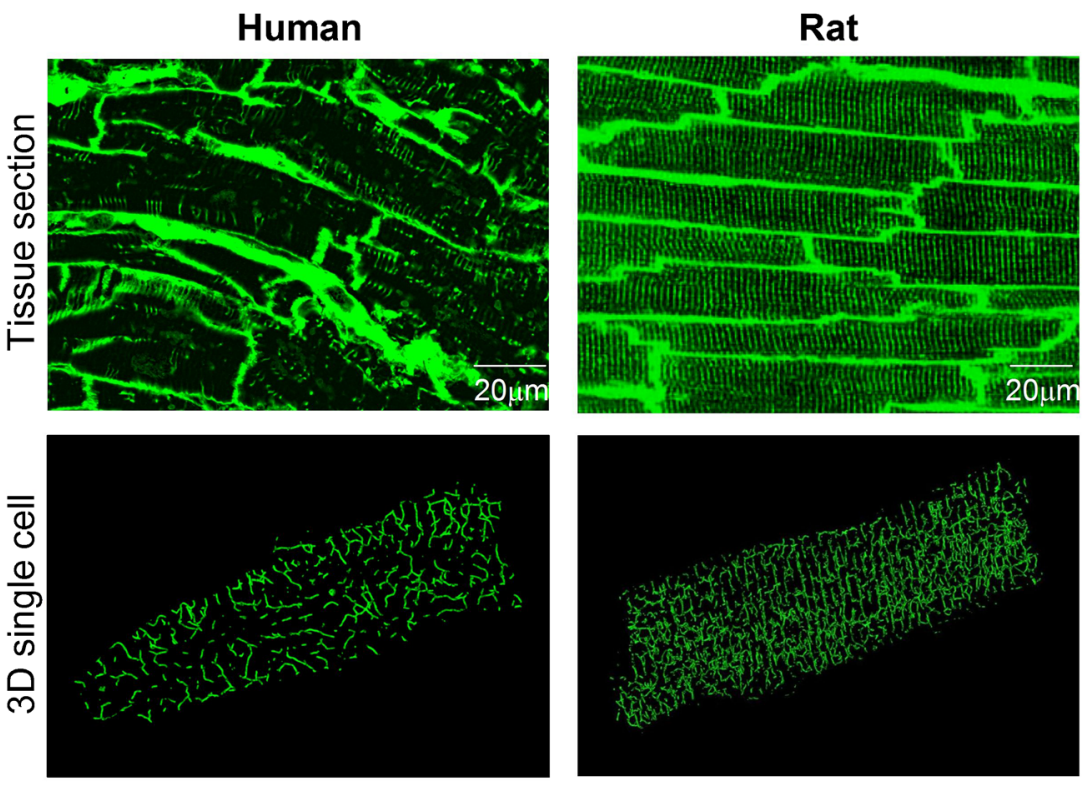

\section{B Atrium}
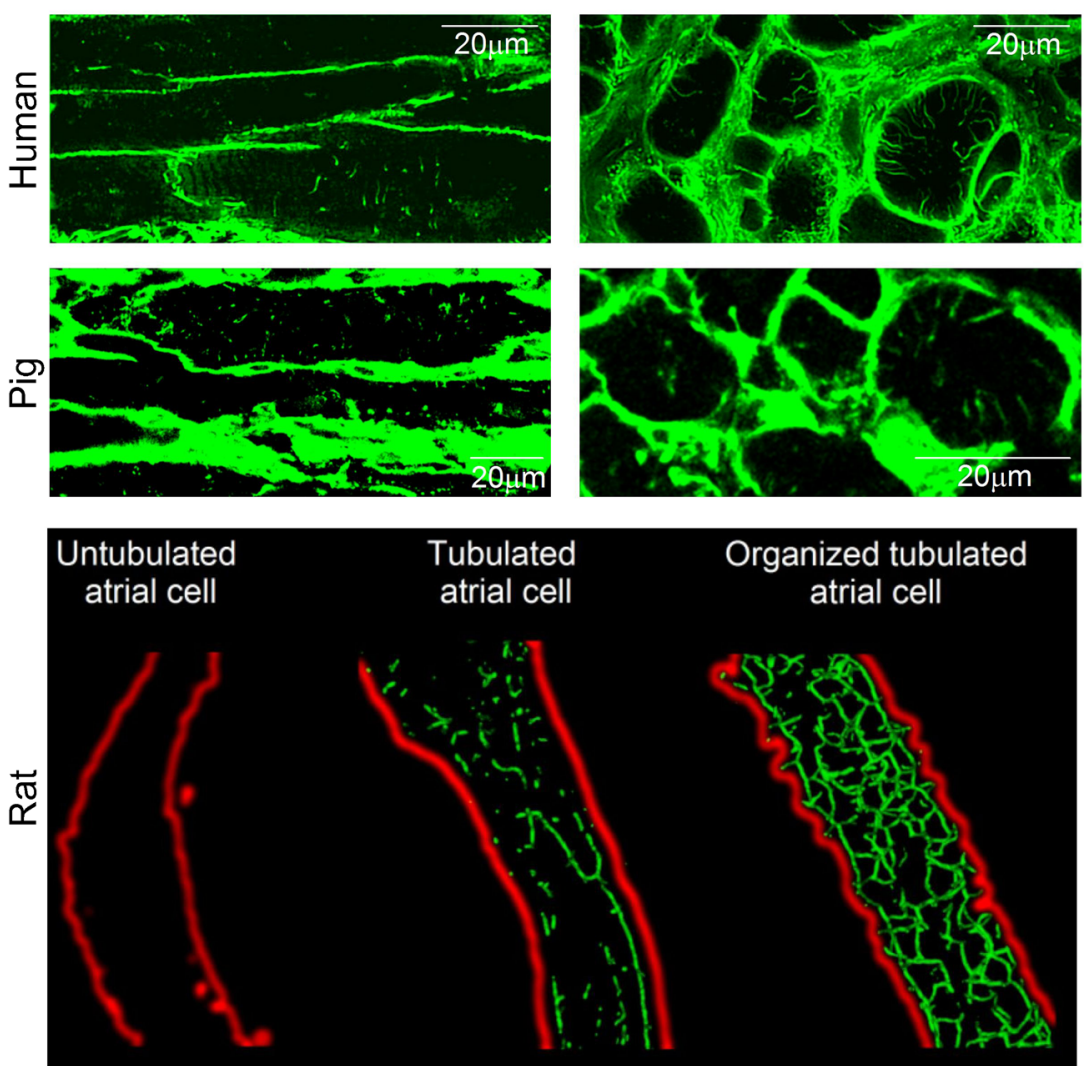

earlier t-tubule development than small rodents, with appearance of t-tubules in utero [45], suggesting that there are significant species-dependent differences in the time course of maturation. Importantly, RyRs are localized at internal, rudimentary SR cisternae prior to the growth of t-tubules in developing cardiomyocytes $[44,46]$. Thus, the action potential of immature cardiomyocytes induces a wave-like propagation of $\mathrm{Ca}^{2+}$ from the surface sarcolemma toward orphaned RyRs at the cell interior [47]. The appearance of t-tubules and assembly of LTCCs into dyads coincides with an augmenting 


\section{A Normal cardiomyocyte}

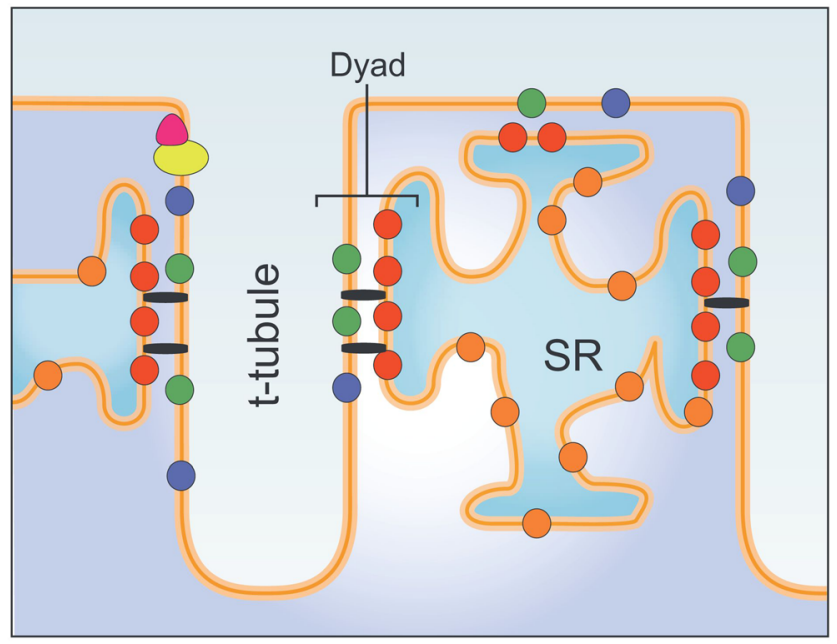

\section{B Diseased cardiomyocyte}
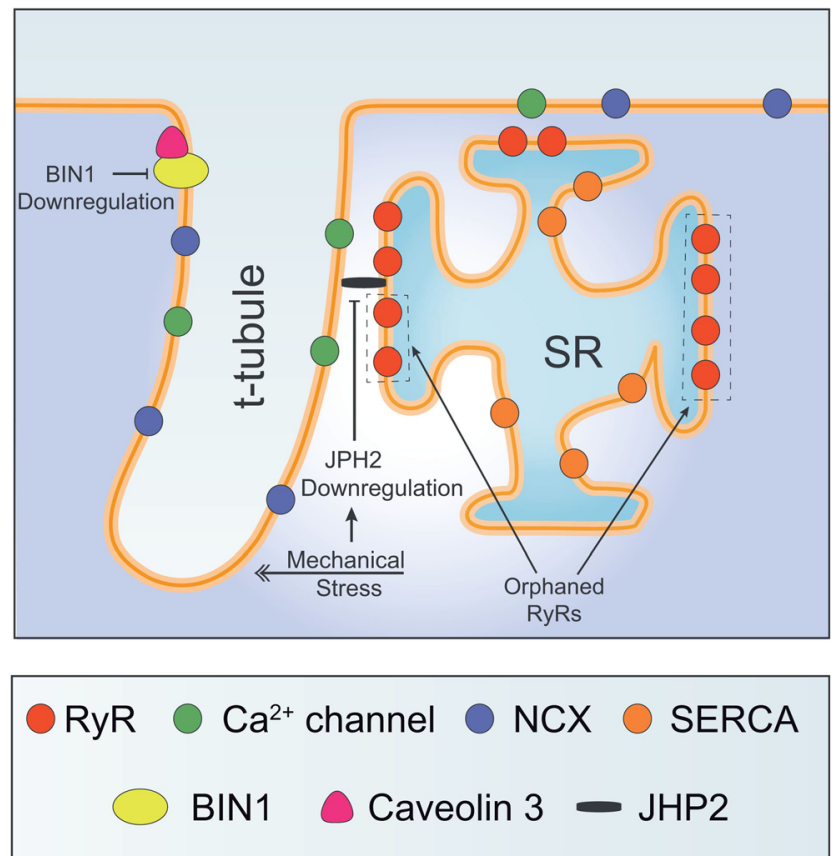

Fig. 2 T-tubule structure in normal and failing cardiac myocytes. a In healthy cardiomyocytes, L-type $\mathrm{Ca}^{2+}$ channels in the t-tubules are apposed from ryanodine receptors (RyRs) in the sarcoplasmic reticulum (SR). Excitation-contraction coupling occurs at these dyadic junctions, which are maintained by Junctophilin-2 (JPH2) and BIN1, and dynamically regulated by workload. b Elevated workload during heart failure has been linked to downregulation of JPH2 and BIN1, and disorganization/loss of t-tubules. Such remodeling results in the formation of orphaned RyRs, which are uncoupled from $\mathrm{Ca}^{2+}$ channels, reduced efficiency of $\mathrm{Ca}^{2+}$-induced $\mathrm{Ca}^{2+}$ release, and impaired contractility in this condition. Novel opportunities for cellular-level heart failure therapies include mitigation of workload/ mechanotransduction and strategies for elevating JPH2 and BIN1 expression role in NCX-mediated $\mathrm{Ca}^{2+}$ extrusion, and maturation of this adult-like mode of $\mathrm{Ca}^{2+}$ cycling corresponds temporally with strengthening of systole and diastole (reviewed in [48]).

Further evidence of $t$-tubule malleability has come from studies of cardiac pathology. A large body of evidence from a number of research groups [38-40,49-57] has indicated that heart failure is associated with marked t-tubule reorganization in both human patients and animal models (Reviewed in [58-61]). Although the specific etiologies underlying heart failure have varied across these studies, spanning chronic ischemia, infarction, aortic stenosis, diabetes, and dilated cardiomyopathy, remarkably similar changes in t-tubular structure are reported $[58,59]$. These alterations include reduction in t-tubule density, an increased fraction of longitudinallyoriented tubules, and t-tubule dilation (Fig. 3 A-C). Interestingly, t-tubule reorganization appears to not be restricted to left ventricular myocytes during heart failure, as similar findings have been reported in the right ventricle $[3,64]$ and in atrial cells $[5,15,16,65,66]$. Comparable atrial t-tubule reorganization resembling that reported in heart failure has been reported in atrial fibrillation $[15,16]$. Thus, an emerging narrative indicates that there is impressive plasticity of t-tubule structure in all chambers of the heart, which is manifested across a range of cardiac pathologies.

As in developing cells, a low density of poorly organized ttubules promotes de-synchronized and protracted $\mathrm{Ca}^{2+}$ release in failing cardiomyocytes (Fig. 3 a-c) [38, 39, 43]. This slowed $\mathrm{Ca}^{2+}$ transient has been coupled to the slowed and decreased amplitude of contraction that is a hallmark of the failing heart $[67,68]$. Indeed, time course studies have indicated that t-tubule disruption occurs prior to the development of heart failure, suggesting that changing t-tubule structure may play a causative role in driving disease progression [3, 57]. Importantly, beyond the overt alterations in t-tubule structure, smaller dyadic-scale changes are also suggested to contribute to de-synchronization of $\mathrm{Ca}^{2+}$ release, including dispersion of RyR clusters which slows $\mathrm{Ca}^{2+}$ sparks [69]. Loss of various t-tubule-localized membrane currents can also desynchronize $\mathrm{Ca}^{2+}$ release by re-shaping the action potential [70-72]. Furthermore, the impaired force-frequency response, characteristic of failing cells, may be related to t-tubule loss. As pacing frequency increases, a marked elevation of intracellular $\mathrm{Na}^{+}$levels occurs which, via NCX, leads to gain of SR $\mathrm{Ca}^{2+}$ content and release. Removal of NCX along with ttubules diminishes this response [73].

In addition to negative effects of t-tubule reorganization on contractility in the failing heart, altered t-tubule structure is believed to have rather complex consequences for arrhythmia generation (reviewed in [74]). Delayed afterdepolarizations (DADs) result from spontaneously released $\mathrm{Ca}^{2+}$ being extruded by NCX. For reasons which are not entirely clear, $\mathrm{Ca}^{2+}$ sparks occur almost exclusively at intact dyads where t-tubules are present [27], and several studies have reported 


\section{A Post-MI, mouse}

Sham

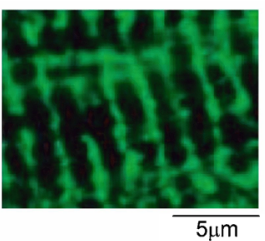

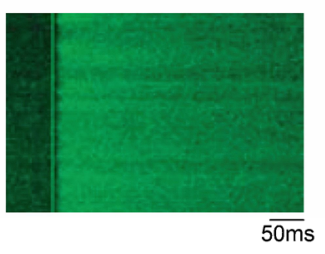

B Spontaneous hypertension, rat Wild-type
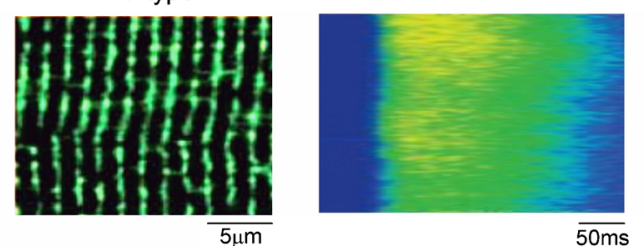

$\mathrm{HF}$
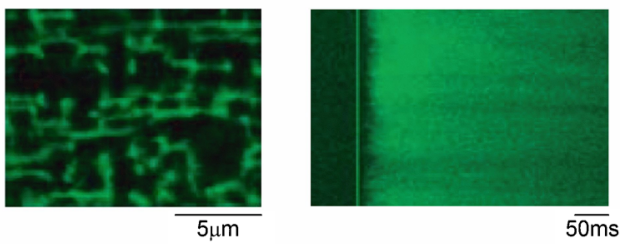

$\mathrm{HF}$

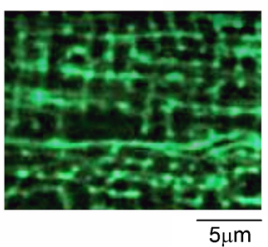

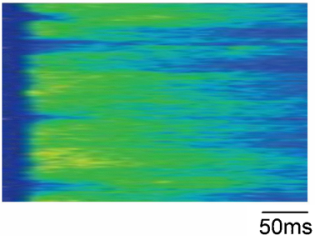

HF
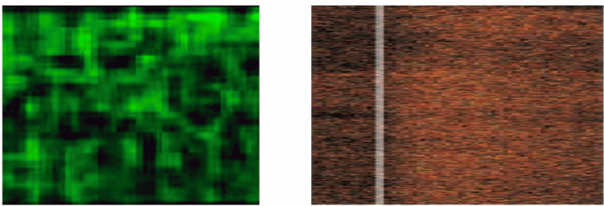

D Increased diastolic wall stress disrupts t-tubules, $\mathrm{Ca}^{2+}$ release, and reduces

JPH2 expression
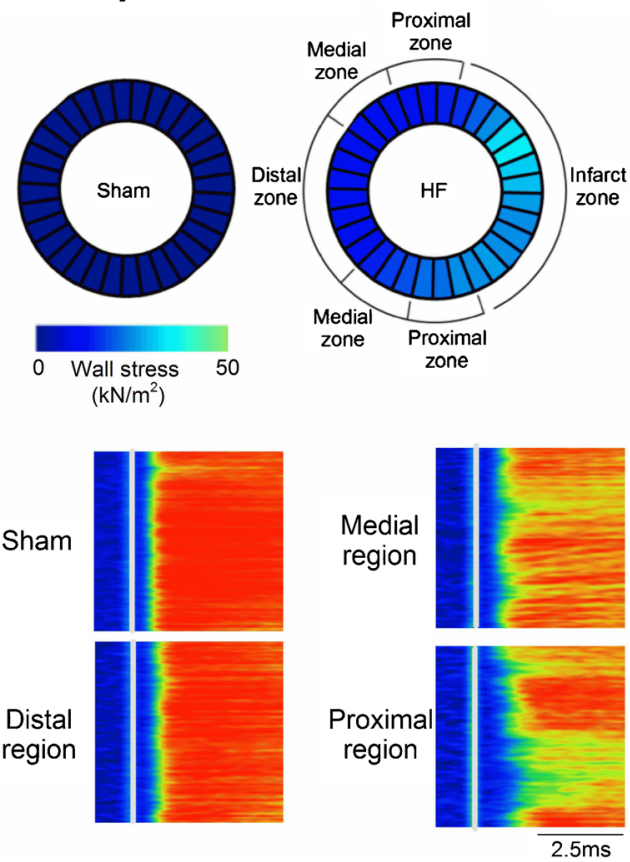

Fig. 3 Structural and functional alterations in t-tubules during heart failure. a-c Confocal images of t-tubular structure (di-8-ANEPPS staining) in healthy and diseased ventricular cardiomyocytes. The wellorganized t-tubule network observed in myocytes from wild-type and sham-operated hearts is lost and disorganized during heart failure resulting from myocardial infarction, hypertension, and diabetes. This structural remodeling results in de-synchronized $\mathrm{Ca}^{2+}$ release across the
Sham

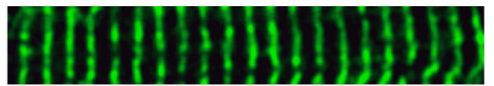

Distal

region

Medial region

Proximal region
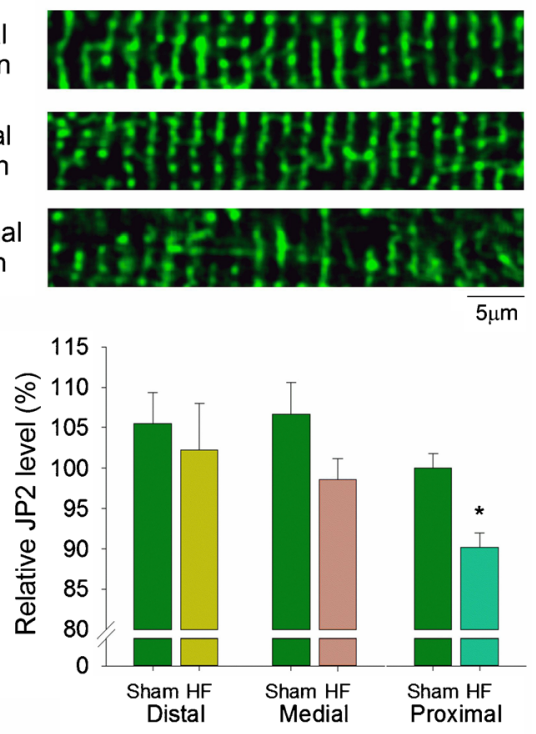

cell, as indicated by confocal line-scan images. Images are modified from a: [38]; b: [39]; c: [62]. d Elevated ventricular wall stress leads to t-tubule disruption. In the post-infarction failing rat heart, high wall stress proximal to the infarct is associated with regional reduction of JPH2 expression, t-tubule loss and dyssynchrony of $\mathrm{Ca}^{2}$ release (modified from [63•]). All images reproduced with permission. [39] Copyright (2006) National Academy of Sciences 
low $\mathrm{Ca}^{2+}$ spark generation at orphaned RyRs $[69,75]$. Furthermore, if an orphaned RyR cluster does generate a $\mathrm{Ca}^{2+}$ spark, DAD generation will be minimized since NCX is not located nearby $[33,76]$. On the other hand, upon generation of a full-blown $\mathrm{Ca}^{2+}$ wave, fewer nearby NCX proteins in t-tubules will mean that less $\mathrm{Ca}^{2+}$ is pulled away from the developing wave front, making its propagation more likely. Ttubule reorganization during heart failure may have similarly complex and opposing effects on the generation of early afterdepolarizations (EADs). Loss of $\mathrm{Ca}^{2+}$ and NCX currents along with t-tubules is expected to shorten the action potential, making phase 2 EADs less likely but phase 3 EADs more likely $[74,76]$. Shorter action potentials and shorter refractory period additionally increase the likelihood of re-entry. Thus, although this remains a developing field, there is certainly evidence to suggest that therapeutic t-tubule protection and repair, discussed in the following section, may benefit inotropy while inhibiting arrhythmia in the failing heart.

\section{T-Tubule Regulators-Opportunities for Therapy}

The striking similarity between t-tubule structure in developing and failing cardiomyocytes has led to speculation that ttubule disruption during heart failure may be linked to reemergence of the fetal gene program in this disease [48]. Indeed, recent data identifying molecular regulators of ttubule structure indicate that the late stages of dyadic assembly are likely amongst the first to be reversed during heart failure development. Although our understanding of the common signals underlying these disparate conditions remains in its infancy, once recognized, manipulation of these pathways could be harnessed for novel disease treatments. Such approaches may aim to safeguard t-tubular structure, or possibly grow new dyads [77]. Understanding the signaling pathways controlling t-tubule structure and growth is additionally hoped to have applications for the therapeutic maturation of cardiac stem cells, as at present these cells retain a quite immature phenotype [78, 79]. However, even before a full comprehension of t-tubule-controlling signals is attained, therapeutic intervention may be possible through manipulation of players already shown to be involved in dyadic assembly. While not necessarily addressing the root causes of dyadic breakdown, modulation of these players has shown early promise at the pre-clinical level, as outlined below.

\section{Junctophilin-2}

Junctophilin-2 (JPH2) is a structural membrane protein that anchors the sarcolemma to the SR [80-83] (Fig. 2). This protein is characterized by a cytoplasmic MORN (membrane on receptor nexus) motif which affixes to the sarcolemma and a transmembrane domain embedded in the SR. The critical role of JPH2 in forming dyads is supported by the parallel appearance of JPH2 and t-tubules along z-lines during development [44]. Furthermore, JPH2 knockdown prevents full t-tubule maturation, leading to heart failure in developing mice [84, 85]. It appears that JPH2 is similarly important for maintaining established dyads in adult cardiomyocytes, as JPH2 downregulation during heart failure has been linked to t-tubule remodeling [3, 54, 63•, 64, 86, 87]. Recent data from our laboratory showed further evidence of pairing of JPH2 expression and t-tubule organization across failing, post-infarction hearts, with the most marked loss of JPH2 and t-tubules observed in regions neighboring the infarct [63•]. Of note, JPH2 has been suggested to anchor transverse but not longitudinal elements of t-tubules [84], consistent with the observation that decreased JPH2 expression during heart failure is associated with an increasingly longitudinal t-tubule orientation. Importantly, while some longitudinal elements present in failing cells may be those which have become unthethered and drifted following JPH2 loss, others are newly grown, and this can occur even in the presence of an intact transverse tubule population [22].

More detailed insight into the role of JPH2 in dyadic organization has been provided by nanoscale super-resolution imaging techniques. Munro and colleagues recently reported that JPH2 overexpression resulted in the formation of larger RyR clusters within CRUs [88]. In apparent support of a role for JPH2 in localizing dyadic RyRs, Wang et al. observed reduced co-localization of RyRs with NCX following JPH2 knockdown [31]. Exciting recent data suggest that JPH2 binding might not only localize RyRs to the dyad, but also stabilizes channel function, as RyR hyperactivity has been reported following JPH2 knockdown [89]. Similarly, a mutation of JPH2 (E169K) which reduces its binding to RyR was observed to increase RyR opening (leak) [90], while JPH2 overexpression was associated with inhibition of $\mathrm{Ca}^{2+}$ sparks [88]. Other proposed regulatory roles of JPH2 in the dyad include modulation of LTCCs, as reported previously in skeletal muscle [91] and recently in heart [92].

The precise mechanisms responsible for promoting JPH2 downregulation during heart failure continue to be examined. Data from our group indicate that elevated ventricular wall stress is an important trigger of JPH2 suppression (discussed below, [63•]), and while we did not identify the intermediate signaling pathway, interesting data from the Wang group have implicated a key role of miR-24 upregulation [93, 94]. Recently reported calpain cleavage of JPH2 [95] may also be expected to be augmented in the failing heart.

As there is now considerable evidence linking JPH2 downregulation to impaired $\mathrm{Ca}^{2+}$ homeostasis and arrhythmia in heart failure, this protein is considered to be a promising therapeutic target. JPH2 overexpression has been observed to restore t-tubule structure and abnormal SR $\mathrm{Ca}^{2+}$ release in failing cardiomyocytes, attenuating disease progression $[96,97 \bullet]$. 
A putative alternative strategy for protecting JPH2 expression in the failing heart is via inhibition of miR-24, and $\mathrm{Li}$ and colleagues observed that miR-24 suppression did indeed prevent transition from compensated to decompensated hypertrophy [94]. However, miR-24 is also reported to play a key role in protecting the heart against apoptosis following ischemia [95], suggesting that miR-24 inhibition may not be a suitable treatment for all heart failure etiologies. As yet untested strategies for protecting JPH2 levels in the failing heart include blockade of JPH2 cleavage by calpain [98], or other degradation pathways. While these ideas are promising, it is important to note that present data supporting a potential therapeutic role of JPH2 in heart failure come almost exclusively from small rodents. Thus, future investigations will certainly require advancement to larger animal models to demonstrate possible relevance for human patients.

\section{Bridging Integrator-1 (BIN1)}

The membrane scaffolding protein BIN1, or amphiphysin-2, plays an important role in dyadic assembly and maintenance [99-101]. The protein is expressed in several tissue specific isoforms. While the skeletal muscle isoform has long been known to induce tubulogenesis in this tissue [100, 102], the precise roles of the cardiac isoform have been recognized more recently. Four different splice variants are expressed in the mouse heart, and have been named according to their included exons: BIN1 (excluding exons 7, 11, and 13-17), BIN1+17 (including exon 17), BIN1+13, and BIN1+13+17 $[103 \bullet]$. BIN1+13 is the most abundant of these variants and is primarily involved with cell proliferation [104]. BIN1+13+17 on the other hand, promotes t-tubular growth, and folding of the membrane to create microdomains [101, 103•, 105]. These microdomains are believed to be the target for the previously demonstrated trafficking of LTCCs along microtubules to the t-tubule membrane [101]. In addition to facilitating membrane folding, BIN1+13+17 also anchors the growing end of LTCCtransporting microtubules in a process known as targeted delivery [103•]. The same isoform has been shown to attract phosphorylated RyRs on the SR membrane, presumably to ensure close proximity with dyadic LTCCs [106].

Consistent with a key role of BIN1 in forming and sustaining dyads, genetic knockout was observed to be embryonically lethal, and cardiomyocyte-specific deletion to promote dilated cardiomyopathy [107]. Downregulation of BIN1 has been reported in both human and animal models of heart failure, and associated with loss of t-tubules [54, 92, 108, 109]. The mechanism by which BIN1 loss leads to t-tubule membrane degradation is not clear, but may include its role in regulation of phosphoinositides. BIN1 clusters phosphoinositides during ttubule formation, leading to dynamin-2 polymerization [100], and disruption of the phosphoinositide system has been linked to t-tubule degradation in both the heart [110] and skeletal muscle [111]. Key players appear to include myotubularin, a phosphoinositide-3 phosphatase [112], and phosphoinositide 3 kinases [110].

The consequences of BIN1 loss during heart failure are proposed to include macroscale loss of t-tubule membrane and functional dyads, with expected negative consequences for EC coupling efficiency. However, nanometer scale alterations may also be critical. Hong et al., have suggested that ttubule dismantling includes a less folded t-tubule membrane which increases arrhythmia susceptibility by allowing augmented ionic diffusion within the t-tubule lumen [103•]. Furthermore, BIN1's reported role in trafficking LTCCs and RyRs to the dyad may contribute to unpacking of these proteins when BIN1 levels decline during heart failure progression.

Given the role of BIN1 in organizing t-tubule membrane folds and dyads it may be a potential target for future therapy. While existing data suggest that increasing BIN1 levels in heart failure might simultaneously augment contractility and attenuate arrhythmogenesis, such studies have not yet been conducted. However, given what appears to be rather complex interaction between BIN1 and a variety of lipid and protein partners, therapeutic manipulation of this system may not be straight forward.

\section{Load}

Accumulating evidence supports a key role of workload as a dynamic regulator of t-tubular structure (reviewed in [113]). While increased workload during heart failure has been linked to t-tubule disruption in a large number of studies, it appears that such remodeling is reversible upon unloading of failing hearts. The Terracciano group has demonstrated this point by performing heterotopic transplantation of hearts from failing rats [113]. Similar findings have been made with pharmacological interventions that unload the failing heart, such as sildenafil and $\beta_{1}$-receptor blockers [64, 86, 114]. Similarly, resynchronization therapy has been observed to improve cardiac function by restoring the t-tubule network in dyssynchronous heart failure [115]. Interestingly, Ibrahim and colleagues observed that unloading healthy hearts promoted t-tubule loss [116]. Thus, these authors have proposed that there is an optimal range of loads which is necessary to maintain t-tubules [113].

Workload is of course a rather nonspecific term, which may encompass many aspects of cardiac function. In an effort to more specifically identify signals which relate cardiac workload to t-tubular remodeling, we recently examined the role of ventricular wall stress [63•]. We found that wall stress was negatively correlated with t-tubule density across the postinfarction failing heart, with a marked elevation of wall stress and loss of t-tubules observed in regions neighboring the infarct (Fig. 3D). In situ experiments confirmed a causal nature 
of this relationship, as stretching papillary muscles to reproduce high, in vivo levels of wall stress signaled t-tubule degradation [63•]. While the underlying mechanism includes JPH2 downregulation, the critical stretch/wall stretch sensors which detect and relay these signals remain to be determined. One promising candidate is the z-disc protein titin cap (Tcap). Tcap loss has been demonstrated during heart failure [55, 108] and Tcap knockout mice have been observed to exhibit progressive disruption of the t-tubule network during development [117]. Augmented expression of Tcap, on the other hand, is associated with recovery of t-tubules, for example during reverse remodeling induced by SERCA2a gene therapy [108].

Workload-dependent regulation of t-tubules has important therapeutic implications. As noted above, this mechanism has already been linked to the benefits of existing load-reducing drugs, but also likely contributes to the benefits of therapies such as ventricular assist devices [113]. Quantitative understanding of how workload parameters, such as ventricular wall stress, regulate t-tubule morphology could be envisioned to guide the application of such therapies. Future treatment strategies might alternatively directly inhibit the mechanosensing that signals t-tubule remodeling, although at present our understanding of these pathways is limited to only a couple putative players (Tcap, JPH2). Intriguing recent data suggest that the t-tubules themselves can transduce mechanical signals during stretch and contraction $[118,119]$ and possibly thereby regulate their own structure. If true, t-tubule membrane malleability might be clinically targeted, in an effort to perhaps counteract stiffening of the t-tubule lumen due to collagen deposition (Crossman et al., Cardiovasc Res [120]).

\section{Conclusion}

The above discussion has highlighted the impressive plasticity of cardiomyocyte t-tubular structure, and its central importance in regulating cellular $\mathrm{Ca}^{2+}$ homeostasis, contractility, and arrhythmic potential. While loss and disorganization of t-tubules is now understood to be an important cellular-level contributor to heart failure, the malleability of this system may also be harnessed for therapy. Potential therapeutic targets include JPH2 and BIN1, which are critical for dyad formation and maintenance, and are downregulated in the failing heart. As recent data indicate that expression of these dyadic stabilizers is at least in part controlled by workload, future therapies may act to more effectively unload the failing heart and/or disrupt mechanotransduction.

\section{Compliance with Ethical Standards}

Conflict of Interest Ornella Manfra, Michael Frisk, and William E. Louch declare no conflict of interest.
Human and Animal Rights Previously unpublished images of ttubules in human ventricular tissue (Fig. 1a, left panels) were performed on biopsies taken from healthy organ donors with hearts deemed unsuitable for transplant. This work was approved by the Regional Ethics Committee (project S-05172) in agreement with The Declaration of Helsinki and the Council of Europe Convention on Human Rights and Biomedicine.

Funding Generous funding has been provided by the European Union's Horizon 2020 research and innovation program (Consolidator grant, WEL) under grant agreement No 647714. Additional support has been received from The South-Eastern Norway Regional Health Authority, Anders Jahre's Fund for the Promotion of Science, The Norwegian Institute of Public Health, Oslo University Hospital Ullevål, and the University of Oslo.

Open Access This article is distributed under the terms of the Creative Commons Attribution 4.0 International License (http:// creativecommons.org/licenses/by/4.0/), which permits unrestricted use, distribution, and reproduction in any medium, provided you give appropriate credit to the original author(s) and the source, provide a link to the Creative Commons license, and indicate if changes were made.

\section{References}

Papers of particular interest, published recently, have been highlighted as:

- Of importance

1. Lindner E. Submicroscopic morphology of the cardiac muscle. Zeitschrift fur Zellforschung und mikroskopische Anatomie (Vienna, Austria: 1948). 1957;45(6):702-46.

2. Huxley AF. The activation of striated muscle and its mechanical response. Proceedings of the Royal Society of London Series B, Biological sciences. 1971;178(1050):1-27.

3. Wei S, Guo A, Chen B, Kutschke W, Xie YP, Zimmerman K, et al. T-tubule remodeling during transition from hypertrophy to heart failure. Circ Res. 2010;107(4):520-31. doi:10.1161/circresaha. 109.212324.

4. Frisk M, Koivumaki JT, Norseng PA, Maleckar MM, Sejersted $\mathrm{OM}$, Louch WE. Variable t-tubule organization and $\mathrm{Ca}^{2+}$ homeostasis across the atria. Am J Physiol Heart Circ Physiol. 2014;307(4):H609-20. doi:10.1152/ajpheart.00295.2014.

5. Richards MA, Clarke JD, Saravanan P, Voigt N, Dobrev D, Eisner $\mathrm{DA}$, et al. Transverse tubules are a common feature in large mammalian atrial myocytes including human. Am J Physiol Heart Circ Physiol. 2011;301(5):H1996-2005. doi:10.1152/ajpheart.00284. 2011.

6. Soeller C, Cannell MB. Examination of the transverse tubular system in living cardiac rat myocytes by 2-photon microscopy and digital image-processing techniques. Circ Res. 1999;84(3): 266-75.

7. Brette F, Orchard C. T-tubule function in mammalian cardiac myocytes. Circ Res. 2003;92(11):1182-92. doi:10.1161/01.RES. 0000074908.17214.FD

8. Hayashi T, Martone ME, Yu Z, Thor A, Doi M, Holst MJ, et al. Three-dimensional electron microscopy reveals new details of membrane systems for $\mathrm{Ca}^{2+}$ signaling in the heart. J Cell Sci. 2009;122(Pt 7):1005-13. doi:10.1242/jcs.028175.

9. Bers DM. Cardiac excitation-contraction coupling. Nature. 2002;415(6868):198-205. doi:10.1038/415198a. 
10. Severs NJ, Slade AM, Powell T, Twist VW, Jones GE. Morphometric analysis of the isolated calcium-tolerant cardiac myocyte. Organelle volumes, sarcomere length, plasma membrane surface folds, and intramembrane particle density and distribution. Cell Tissue Res. 1985;240(1):159-68.

11. Stewart JM, Page E. Improved stereological techniques for studying myocardial cell growth: application to external sarcolemma, $\mathrm{T}$ system, and intercalated disks of rabbit and rat hearts. J Ultrastruct Res. 1978;65(2):119-34.

12. Cannell MB, Crossman DJ, Soeller C. Effect of changes in action potential spike configuration, junctional sarcoplasmic reticulum micro-architecture and altered t-tubule structure in human heart failure. J Muscle Res Cell Motil. 2006;27(5-7):297-306. doi:10. 1007/s10974-006-9089-y.

13. Savio-Galimberti E, Frank J, Inoue M, Goldhaber JI, Cannell MB, Bridge $\mathrm{JH}$, et al. Novel features of the rabbit transverse tubular system revealed by quantitative analysis of three-dimensional reconstructions from confocal images. Biophys J. 2008;95(4):205362. doi:10.1529/biophysj.108.130617.

14. Walden AP, Dibb KM, Trafford AW. Differences in intracellular calcium homeostasis between atrial and ventricular myocytes. J Mol Cell Cardiol. 2009;46(4):463-73. doi:10.1016/j.yjmcc.2008. 11.003 .

15. Lenaerts I, Bito V, Heinzel FR, Driesen RB, Holemans P, D'Hooge $\mathrm{J}$, et al. Ultrastructural and functional remodeling of the coupling between $\mathrm{Ca}^{2+}$ influx and sarcoplasmic reticulum $\mathrm{Ca}^{2+}$ release in right atrial myocytes from experimental persistent atrial fibrillation. Circ Res. 2009;105(9):876-85. doi:10.1161/circresaha.109. 206276.

16. Dibb KM, Clarke JD, Horn MA, Richards MA, Graham HK, Eisner DA, et al. Characterization of an extensive transverse tubular network in sheep atrial myocytes and its depletion in heart failure. Circulation Heart failure. 2009;2(5):482-9. doi:10.1161/ circheartfailure.109.852228.

17. Smyrnias I, Mair W, Harzheim D, Walker SA, Roderick HL, Bootman MD. Comparison of the T-tubule system in adult rat ventricular and atrial myocytes, and its role in excitationcontraction coupling and inotropic stimulation. Cell Calcium. 2010;47(3):210-23. doi:10.1016/j.ceca.2009.10.001.

18. Kirk MM, Izu LT, Chen-Izu Y, McCulle SL, Wier WG, Balke CW, et al. Role of the transverse-axial tubule system in generating calcium sparks and calcium transients in rat atrial myocytes. $\mathrm{J}$ Physiol. 2003;547(Pt 2):441-51. doi:10.1113/jphysiol.2002. 034355.

19. Arora R, Aistrup GL, Supple S, Frank C, Singh J, Tai S, et al. Regional distribution of T-tubule density in left and right atria in dogs. Heart Rhythm. 2016; doi:10.1016/j.hrthm.2016.09.022.

20. Glukhov AV, Balycheva M, Sanchez-Alonso JL, Ilkan Z, AlvarezLaviada A, Bhogal N, et al. Direct evidence for microdomainspecific localization and remodeling of functional L-type calcium channels in rat and human atrial myocytes. Circulation. 2015;132(25):2372-84. doi:10.1161/CIRCULATIONAHA.115. 018131.

21. Pinali C, Bennett H, Davenport JB, Trafford AW, Kitmitto A. Three-dimensional reconstruction of cardiac sarcoplasmic reticulum reveals a continuous network linking transverse-tubules: this organization is perturbed in heart failure. Circ Res. 2013;113(11): 1219-30. doi:10.1161/circresaha.113.301348.

22. Swift F, Franzini-Armstrong C, Oyehaug L, Enger UH, Andersson $\mathrm{KB}$, Christensen G, et al. Extreme sarcoplasmic reticulum volume loss and compensatory T-tubule remodeling after Serca2 knockout. Proc Natl Acad Sci U S A. 2012;109(10):3997-4001. doi:10. 1073/pnas.1120172109.

23. Sun XH, Protasi F, Takahashi M, Takeshima H, Ferguson DG, Franzini-Armstrong C. Molecular architecture of membranes involved in excitation-contraction coupling of cardiac muscle. $\mathrm{J}$ Cell Biol. 1995;129(3):659-71.

24. Schulson MN, Scriven DR, Fletcher P, Moore ED. Couplons in rat atria form distinct subgroups defined by their molecular partners. $J$ Cell Sci. 2011;124(Pt 7):1167-74. doi:10.1242/jcs.080929.

25. Bers DM, Stiffel VM. Ratio of ryanodine to dihydropyridine receptors in cardiac and skeletal muscle and implications for E-C coupling. Am J Phys. 1993;264(6 Pt 1):C1587-93.

26. Baddeley D, Jayasinghe ID, Lam L, Rossberger S, Cannell MB, Soeller C. Optical single-channel resolution imaging of the ryanodine receptor distribution in rat cardiac myocytes. Proc Natl Acad Sci U S A. 2009;106(52):22275-80. doi:10.1073/ pnas.0908971106.

27. Cheng H, Lederer WJ, Cannell MB. Calcium sparks: elementary events underlying excitation-contraction coupling in heart muscle. Science (New York, NY). 1993;262(5134):740-4.

28. Lipp P, Niggli E. Submicroscopic calcium signals as fundamental events of excitation-contraction coupling in guinea-pig cardiac myocytes. J Physiol. 1996;492(Pt 1):31-8.

29. Despa S, Brette F, Orchard CH, Bers DM. Na/Ca exchange and $\mathrm{Na} / \mathrm{K}$-ATPase function are equally concentrated in transverse tubules of rat ventricular myocytes. Biophys J. 2003;85(5):3388-96. doi:10.1016/s0006-3495(03)74758-4.

30. Jayasinghe ID, Cannell MB, Soeller C. Organization of ryanodine receptors, transverse tubules, and sodium-calcium exchanger in rat myocytes. Biophys J. 2009;97(10):2664-73. doi:10.1016/j.bpj. 2009.08.036.

31. Wang W, Landstrom AP, Wang Q, Munro ML, Beavers D, Ackerman MJ, et al. Reduced junctional $\mathrm{Na}^{+} / \mathrm{Ca}^{2+}$-exchanger activity contributes to sarcoplasmic reticulum $\mathrm{Ca}^{2+}$ leak in junctophilin-2-deficient mice. Am J Physiol Heart Circ Physiol. 2014;307(9):H1317-26. doi:10.1152/ajpheart.00413.2014.

32. Mohler PJ, Davis JQ, Bennett V. Ankyrin-B coordinates the $\mathrm{Na}^{+} /$ $\mathrm{K}+$ ATPase, $\mathrm{Na}^{+} / \mathrm{Ca}^{2+}$ exchanger, and InsP3 receptor in a cardiac T-tubule/SR microdomain. PLoS Biol. 2005;3(12):e423. doi:10. 1371/journal.pbio.0030423.

33. Biesmans L, Macquaide N, Heinzel FR, Bito V, Smith GL, Sipido KR. Subcellular heterogeneity of ryanodine receptor properties in ventricular myocytes with low T-tubule density. PLoS One. 2011;6(10):e25100. doi:10.1371/journal.pone.0025100.

34. Lines GT, Sande JB, Louch WE, Mork HK, Grottum P, Sejersted OM. Contribution of the $\mathrm{Na}^{+} / \mathrm{Ca}^{2+}$ exchanger to rapid $\mathrm{Ca}^{2+}$ release in cardiomyocytes. Biophys J. 2006;91(3):779-92. doi:10.1529/ biophysj.105.072447.

35. Sipido KR, Maes M, Van de Werf F. Low efficiency of $\mathrm{Ca}^{2+}$ entry through the $\mathrm{Na}^{+}-\mathrm{Ca}^{2+}$ exchanger as trigger for $\mathrm{Ca}^{2+}$ release from the sarcoplasmic reticulum. A comparison between L-type $\mathrm{Ca}^{2+}$ current and reverse-mode $\mathrm{Na}^{+}-\mathrm{Ca}^{2+}$ exchange. Circ Res. 1997;81(6):1034-44.

36. Henderson SA, Goldhaber JI, So JM, Han T, Motter C, Ngo A, et al. Functional adult myocardium in the absence of $\mathrm{Na}^{+}-\mathrm{Ca}^{2+}$ exchange: cardiac-specific knockout of NCX1. Circ Res. 2004;95(6):604-11. doi:10.1161/01.RES.0000142316.08250.68.

37. Larbig R, Torres N, Bridge JH, Goldhaber JI, Philipson KD. Activation of reverse $\mathrm{Na}^{+}-\mathrm{Ca}^{2+}$ exchange by the $\mathrm{Na}^{+}$current augments the cardiac $\mathrm{Ca}^{2+}$ transient: evidence from NCX knockout mice. J Physiol. 2010;588(Pt 17):3267-76. doi:10.1113/jphysiol. 2010.187708.

38. Louch WE, Mork HK, Sexton J, Stromme TA, Laake P, Sjaastad I, et al. T-tubule disorganization and reduced synchrony of $\mathrm{Ca}^{2+}$ release in murine cardiomyocytes following myocardial infarction. J Physiol. 2006;574(Pt 2):519-33. doi:10.1113/jphysiol. 2006.107227.

39. Song LS, Sobie EA, McCulle S, Lederer WJ, Balke CW, Cheng $\mathrm{H}$. Orphaned ryanodine receptors in the failing heart. Proc Natl 
Acad Sci U S A. 2006;103(11):4305-10. doi:10.1073/pnas. 0509324103.

40. Heinzel FR, Bito V, Biesmans L, Wu M, Detre E, von Wegner F, et al. Remodeling of T-tubules and reduced synchrony of $\mathrm{Ca}^{2+}$ release in myocytes from chronically ischemic myocardium. Circ Res. 2008;102(3):338-46. doi:10.1161/circresaha.107. 160085.

41. Heinzel FR, MacQuaide N, Biesmans L, Sipido K. Dyssynchrony of $\mathrm{Ca}^{2+}$ release from the sarcoplasmic reticulum as subcellular mechanism of cardiac contractile dysfunction. J Mol Cell Cardiol. 2011;50(3):390-400. doi:10.1016/j.yjmcc.2010.11.008.

42. Oyehaug L, Loose KO, Jolle GF, Roe AT, Sjaastad I, Christensen $\mathrm{G}$, et al. Synchrony of cardiomyocyte $\mathrm{Ca}^{2+}$ release is controlled by T-tubule organization, SR $\mathrm{Ca}^{2+}$ content, and ryanodine receptor $\mathrm{Ca}^{2+}$ sensitivity. Biophys J. 2013;104(8):1685-97. doi:10.1016/j. bpj.2013.03.022.

43. Louch WE, Bito V, Heinzel FR, Macianskiene R, Vanhaecke J, Flameng W, et al. Reduced synchrony of $\mathrm{Ca}^{2+}$ release with loss of T-tubules-a comparison to $\mathrm{Ca}^{2+}$ release in human failing cardiomyocytes. Cardiovasc Res. 2004;62(1):63-73. doi:10. 1016/j.cardiores.2003.12.031.

44. Ziman AP, Gomez-Viquez NL, Bloch RJ, Lederer WJ. Excitationcontraction coupling changes during postnatal cardiac development. J Mol Cell Cardiol. 2010;48(2):379-86. doi:10.1016/j. yjmcc.2009.09.016.

45. Munro ML, Soeller C. Early transverse tubule development begins in utero in the sheep heart. J Muscle Res Cell Motil. 2017; doi:10.1007/s10974-016-9462-4.

46. Korhonen T, Rapila R, Ronkainen VP, Koivumaki JT, Tavi P. Local $\mathrm{Ca}^{2+}$ releases enable rapid heart rates in developing cardiomyocytes. J Physiol. 2010;588(Pt 9):1407-17. doi:10. 1113/jphysiol.2009.185173.

47. Haddock PS, Coetzee WA, Cho E, Porter L, Katoh H, Bers DM, et al. Subcellular $[\mathrm{Ca} 2+]$ i gradients during excitation-contraction coupling in newborn rabbit ventricular myocytes. Circ Res. 1999;85(5):415-27.

48. Louch WE, Koivumaki JT, Tavi P. Calcium signalling in developing cardiomyocytes: implications for model systems and disease. $\mathrm{J}$ Physiol. 2015;593(5):1047-63. doi:10.1113/jphysiol.2014. 274712.

49. Crocini C, Coppini R, Ferrantini C, Yan P, Loew LM, Tesi C, et al. Defects in T-tubular electrical activity underlie local alterations of calcium release in heart failure. Proc Natl Acad Sci U S A. 2014;111(42):15196-201. doi:10.1073/pnas.1411557111.

50. Ibrahim M, Al Masri A, Navaratnarajah M, Siedlecka U, Soppa GK, Moshkov A, et al. Prolonged mechanical unloading affects cardiomyocyte excitation-contraction coupling, transverse-tubule structure, and the cell surface. FASEB journal : official publication of the Federation of American Societies for Experimental Biology. 2010;24(9):3321-9. doi:10.1096/fj.10-156638.

51. Sachse FB, Torres NS, Savio-Galimberti E, Aiba T, Kass DA, Tomaselli GF, et al. Subcellular structures and function of myocytes impaired during heart failure are restored by cardiac resynchronization therapy. Circ Res. 2012;110(4):588-97. doi: 10.1161/circresaha.111.257428.

52. He J, Conklin MW, Foell JD, Wolff MR, Haworth RA, Coronado $\mathrm{R}$, et al. Reduction in density of transverse tubules and L-type $\mathrm{Ca}^{2+}$ channels in canine tachycardia-induced heart failure. Cardiovasc Res. 2001;49(2):298-307.

53. Wagner E, Lauterbach MA, Kohl T, Westphal V, Williams GS, Steinbrecher JH, et al. Stimulated emission depletion live-cell super-resolution imaging shows proliferative remodeling of T-tubule membrane structures after myocardial infarction. Circ Res. 2012;111(4):402-14. doi:10.1161/circresaha.112.274530.

54. Caldwell JL, Smith CE, Taylor RF, Kitmitto A, Eisner DA, Dibb $\mathrm{KM}$, et al. Dependence of cardiac transverse tubules on the BAR domain protein amphiphysin II (BIN-1). Circ Res. 2014;115(12): 986-96. doi:10.1161/circresaha.116.303448.

55. Bryant S, Kimura TE, Kong CH, Watson JJ, Chase A, Suleiman MS, et al. Stimulation of ICa by basal PKA activity is facilitated by caveolin-3 in cardiac ventricular myocytes. J Mol Cell Cardiol. 2014;68:47-55. doi:10.1016/j.yjmcc.2013.12.026.

56. Crossman DJ, Young AA, Ruygrok PN, Nason GP, Baddelely D, Soeller C, et al. T-tubule disease: relationship between t-tubule organization and regional contractile performance in human dilated cardiomyopathy. J Mol Cell Cardiol. 2015;84:170-8. doi:10. 1016/j.yjmcc.2015.04.022.

57. Shah SJ, Aistrup GL, Gupta DK, O'Toole MJ, Nahhas AF, Schuster $\mathrm{D}$, et al. Ultrastructural and cellular basis for the development of abnormal myocardial mechanics during the transition from hypertension to heart failure. Am J Physiol Heart Circ Physiol. 2014;306(1): H88-100. doi:10.1152/ajpheart.00642.2013.

58. Louch WE, Sejersted OM, Swift F. There goes the neighborhood: pathological alterations in T-tubule morphology and consequences for cardiomyocyte $\mathrm{Ca}^{2+}$ handling. J Biomed Biotechnol. 2010;2010:503906. doi:10.1155/2010/503906.

59. Guo A, Zhang C, Wei S, Chen B, Song LS. Emerging mechanisms of T-tubule remodelling in heart failure. Cardiovasc Res. 2013;98(2):204-15. doi:10.1093/cvr/cvt020.

60. Ibrahim M, Gorelik J, Yacoub MH, Terracciano CM. The structure and function of cardiac t-tubules in health and disease. Proceedings Biological sciences. 2011;278(1719):2714-23. doi: 10.1098/rspb.2011.0624.

61. Hong T, Shaw RM. Cardiac T-tubule microanatomy and function. Physiol Rev. 2017;97(1):227-52. doi:10.1152/physrev.00037.2015.

62. Stolen TO, Hoydal MA, Kemi OJ, Catalucci D, Ceci M, Aasum E, et al. Interval training normalizes cardiomyocyte function, diastolic $\mathrm{Ca}^{2+}$ control, and $\mathrm{SR} \mathrm{Ca}^{2+}$ release synchronicity in a mouse model of diabetic cardiomyopathy. Circ Res. 2009;105(6):52736. doi:10.1161/circresaha.109.199810.

63. Frisk M, Ruud M, Espe EK, Aronsen JM, Roe AT, Zhang L, et al. Elevated ventricular wall stress disrupts cardiomyocyte t-tubule structure and calcium homeostasis. Cardiovasc Res. 2016;112(1):443-51. doi:10.1093/cvr/cvw111. This work relates mechanical stress across the post-infarction failing heart to remodeling of cardiomyocytes structure and function. High ventricular wall stress is specifically linked to loss of JPH2 and t-tubules, impairment of $\mathrm{Ca} 2+$ release, and reduced in vivo contraction.

64. Xie YP, Chen B, Sanders P, Guo A, Li Y, Zimmerman K, et al. Sildenafil prevents and reverses transverse-tubule remodeling and $\mathrm{Ca}^{2+}$ handling dysfunction in right ventricle failure induced by pulmonary artery hypertension. Hypertension (Dallas, Tex: 1979). 2012;59(2):355-62. doi:10.1161/hypertensionaha.111. 180968.

65. Wakili R, Yeh YH, Yan Qi X, Greiser M, Chartier D, Nishida K, et al. Multiple potential molecular contributors to atrial hypocontractility caused by atrial tachycardia remodeling in dogs. Circ Arrhythm Electrophysiol. 2010;3(5):530-41. doi:10.1161/ CIRCEP.109.933036.

66. Melnyk P, Zhang L, Shrier A, Nattel S. Differential distribution of Kir2.1 and Kir2.3 subunits in canine atrium and ventricle. Am J Physiol Heart Circ Physiol. 2002;283(3):H1123-33. doi:10.1152/ ajpheart.00934.2001.

67. Mork HK, Sjaastad I, Sejersted OM, Louch WE. Slowing of cardiomyocyte $\mathrm{Ca} 2+$ release and contraction during heart failure progression in postinfarction mice. Am J Physiol Heart Circ Physiol. 2009;296(4):H1069-79. doi:10.1152/ajpheart.01009.2008.

68. Bokenes J, Aronsen JM, Birkeland JA, Henriksen UL, Louch WE, Sjaastad I, et al. Slow contractions characterize failing rat hearts. Basic Res Cardiol. 2008;103(4):328-44. doi:10.1007/s00395008-0719-y. 
69. Louch WE, Hake J, Mork HK, Hougen K, Skrbic B, Ursu D, et al. Slow $\mathrm{Ca}(2)(+)$ sparks de-synchronize $\mathrm{Ca}(2)(+)$ release in failing cardiomyocytes: evidence for altered configuration of $\mathrm{Ca}(2)(+)$ release units? J Mol Cell Cardiol. 2013;58:41-52. doi:10.1016/j. yjmcc.2013.01.014.

70. Sah R, Ramirez RJ, Backx PH. Modulation of $\mathrm{Ca}^{2+}$ release in cardiac myocytes by changes in repolarization rate: role of phase-1 action potential repolarization in excitation-contraction coupling. Circ Res. 2002;90(2):165-73.

71. Harris DM, Mills GD, Chen X, Kubo H, Berretta RM, Votaw VS, et al. Alterations in early action potential repolarization causes localized failure of sarcoplasmic reticulum $\mathrm{Ca} 2+$ release. Circ Res. 2005;96(5):543-50. doi:10.1161/01.res.0000158966.58380.37.

72. Louch WE, Hake J, Jolle GF, Mork HK, Sjaastad I, Lines GT, et al. Control of $\mathrm{Ca}^{2+}$ release by action potential configuration in normal and failing murine cardiomyocytes. Biophys J. 2010;99(5):1377-86. doi:10.1016/j.bpj.2010.06.055.

73. Fowler MR, Dobson RS, Orchard CH, Harrison SM. Functional consequences of detubulation of isolated rat ventricular myocytes. Cardiovasc Res. 2004;62(3):529-37. doi:10.1016/j.cardiores. 2004.02.008

74. Orchard $\mathrm{CH}$, Bryant SM, James AF. Do t-tubules play a role in arrhythmogenesis in cardiac ventricular myocytes? J Physiol. 2013;591(17):4141-7. doi:10.1113/jphysiol.2013.254540.

75. Brette F, Despa S, Bers DM, Orchard CH. Spatiotemporal characteristics of SR Ca ${ }^{2+}$ uptake and release in detubulated rat ventricular myocytes. J Mol Cell Cardiol. 2005;39(5):804-12. doi:10. 1016/j.yjmcc.2005.08.005.

76. Edwards AG, Louch WE. Species-dependent mechanisms of cardiac arrhythmia: a cellular focus. Clin Med Insights Cardiol. 2017;11. doi:10.1177/1179546816686061.

77. Roe AT, Frisk M, Louch WE. Targeting cardiomyocyte $\mathrm{Ca}^{2+}$ homeostasis in heart failure. Curr Pharm Des. 2015;21(4):431-48.

78. Poon E, Kong CW, Li RA. Human pluripotent stem cell-based approaches for myocardial repair: from the electrophysiological perspective. Mol Pharm. 2011;8(5):1495-504. doi:10.1021/ mp2002363.

79. Karakikes I, Ameen M, Termglinchan V, Wu JC. Human induced pluripotent stem cell-derived cardiomyocytes: insights into molecular, cellular, and functional phenotypes. Circ Res. 2015;117(1): 80-8. doi:10.1161/circresaha.117.305365.

80. Takeshima H, Komazaki S, Nishi M, Iino M, Kangawa K. Junctophilins: a novel family of junctional membrane complex proteins. Mol Cell. 2000;6(1):11-22.

81. Minamisawa S, Oshikawa J, Takeshima H, Hoshijima M, Wang Y, Chien KR, et al. Junctophilin type 2 is associated with caveolin-3 and is down-regulated in the hypertrophic and dilated cardiomyopathies. Biochem Biophys Res Commun. 2004;325(3):852-6. doi:10.1016/j.bbrc.2004.10.107.

82. Han J, Wu H, Wang Q, Wang S. Morphogenesis of T-tubules in heart cells: the role of junctophilin-2. Sci China Life Sci. 2013;56(7):647-52. doi:10.1007/s11427-013-4490-4.

83. Beavers DL, Landstrom AP, Chiang DY, Wehrens XH. Emerging roles of junctophilin-2 in the heart and implications for cardiac diseases. Cardiovasc Res. 2014;103(2):198-205. doi:10.1093/ $\mathrm{cvr} / \mathrm{cvu} 151$

84. Chen B, Guo A, Zhang C, Chen R, Zhu Y, Hong J, et al. Critical roles of junctophilin-2 in T-tubule and excitation-contraction coupling maturation during postnatal development. Cardiovasc Res. 2013;100(1):54-62. doi:10.1093/cvr/cvt180.

85. Reynolds JO, Chiang DY, Wang W, Beavers DL, Dixit SS, Skapura DG, et al. Junctophilin-2 is necessary for T-tubule maturation during mouse heart development. Cardiovasc Res. 2013;100(1):44-53. doi:10.1093/cvr/cvt133.

86. Chen B, Li Y, Jiang S, Xie YP, Guo A, Kutschke W, et al. Betaadrenergic receptor antagonists ameliorate myocyte T-tubule remodeling following myocardial infarction. FASEB journal : official publication of the Federation of American Societies for Experimental Biology. 2012;26(6):2531-7. doi:10.1096/fj.11199505.

87. Zhang C, Chen B, Guo A, Zhu Y, Miller JD, Gao S, et al. Microtubule-mediated defects in junctophilin-2 trafficking contribute to myocyte transverse-tubule remodeling and $\mathrm{Ca}^{2+}$ handling dysfunction in heart failure. Circulation. 2014;129(17): 1742-50. doi:10.1161/circulationaha.113.008452.

88. Munro ML, Jayasinghe ID, Wang Q, Quick A, Wang W, Baddeley $\mathrm{D}$, et al. Junctophilin-2 in the nanoscale organisation and functional signalling of ryanodine receptor clusters in cardiomyocytes. J Cell Sci. 2016;129(23):4388-98. doi:10.1242/jcs.196873.

89. van Oort RJ, Garbino A, Wang W, Dixit SS, Landstrom AP, Gaur $\mathrm{N}$, et al. Disrupted junctional membrane complexes and hyperactive ryanodine receptors after acute junctophilin knockdown in mice. Circulation. 2011;123(9):979-88. doi:10.1161/ circulationaha.110.006437.

90. Beavers DL, Wang W, Ather S, Voigt N, Garbino A, Dixit SS, et al. Mutation E169K in junctophilin-2 causes atrial fibrillation due to impaired RyR2 stabilization. J Am Coll Cardiol. 2013;62(21):2010-9. doi:10.1016/j.jacc.2013.06.052.

91. Golini L, Chouabe C, Berthier C, Cusimano V, Fornaro M, Bonvallet $\mathrm{R}$, et al. Junctophilin 1 and 2 proteins interact with the L-type $\mathrm{Ca}^{2+}$ channel dihydropyridine receptors (DHPRs) in skeletal muscle. J Biol Chem. 2011;286(51):43717-25. doi:10.1074/ jbc.M111.292755.

92. Jiang M, Zhang M, Howren M, Wang Y, Tan A, Balijepalli RC, et al. JPH-2 interacts with Cai-handling proteins and ion channels in dyads: contribution to premature ventricular contractioninduced cardiomyopathy. Heart Rhythm. 2016;13(3):743-52. doi:10.1016/j.hrthm.2015.10.037.

93. Xu M, Wu HD, Li RC, Zhang HB, Wang M, Tao J, et al. Mir-24 regulates junctophilin-2 expression in cardiomyocytes. Circ Res. 2012;111(7):837-41. doi:10.1161/circresaha.112.277418.

94. Li RC, Tao J, Guo YB, Wu HD, Liu RF, Bai Y, et al. In vivo suppression of microRNA-24 prevents the transition toward decompensated hypertrophy in aortic-constricted mice. Circ Res. 2013;112(4):601-5. doi:10.1161/CIRCRESAHA.112.300806.

95. Guo C, Deng Y, Liu J, Qian L. Cardiomyocyte-specific role of miR-24 in promoting cell survival. J Cell Mol Med. 2015;19(1): 103-12. doi:10.1111/jcmm.12393.

96. Guo A, Zhang X, Iyer VR, Chen B, Zhang C, Kutschke WJ, et al. Overexpression of junctophilin-2 does not enhance baseline function but attenuates heart failure development after cardiac stress. Proc Natl Acad Sci U S A. 2014;111(33):12240-5. doi:10.1073/ pnas.1412729111.

97. Reynolds JO, Quick AP, Wang Q, Beavers DL, Philippen LE, Showell J, et al. Junctophilin-2 gene therapy rescues heart failure by normalizing RyR2-mediated $\mathrm{Ca}^{2+}$ release. Int $\mathrm{J}$ Cardiol. 2016;225:371-80. doi:10.1016/j.ijcard.2016.10.021. In this article, JPH2 is suggested as a potential therapeutic target for treating heart failure. Restoration of junctophilin-2 levels is observed to prevent t-tubule loss and normalize $\mathrm{Ca} 2+$ release in failing hearts.

98. Guo A, Hall D, Zhang C, Peng T, Miller JD, Kutschke W, et al. Molecular determinants of calpain-dependent cleavage of junctophilin-2 protein in cardiomyocytes. J Biol Chem. 2015;290(29):17946-55. doi:10.1074/jbc.M115.652396.

99. Muller AJ, Baker JF, DuHadaway JB, Ge K, Farmer G, Donover PS, et al. Targeted disruption of the murine Bin1/Amphiphysin II gene does not disable endocytosis but results in embryonic cardiomyopathy with aberrant myofibril formation. Mol Cell Biol. 2003;23(12):4295-306.

100. Lee E, Marcucci M, Daniell L, Pypaert M, Weisz OA, Ochoa GC, et al. Amphiphysin 2 (Bin1) and T-tubule biogenesis in muscle. 
Science (New York, NY). 2002;297(5584):1193-6. doi:10.1126/ science. 1071362.

101. Hong TT, Smyth JW, Gao D, Chu KY, Vogan JM, Fong TS, et al. BIN1 localizes the L-type calcium channel to cardiac T-tubules. PLoS Biol. 2010;8(2):e1000312. doi:10.1371/journal.pbio. 1000312.

102. Frost A, Unger VM, De Camilli P. The BAR domain superfamily: membrane-molding macromolecules. Cell. 2009;137(2):191-6. doi:10.1016/j.cell.2009.04.010.

103. Hong T, Yang H, Zhang SS, Cho HC, Kalashnikova M, Sun B, et al. Cardiac BIN1 folds T-tubule membrane, controlling ion flux and limiting arrhythmia. Nat Med. 2014;20(6):624-32. doi:10. $1038 / \mathrm{nm} .3543$. The authors report that $\mathrm{t}$-tubules are grown and folded by the BIN1 splice variant BIN1+13+17. It is suggested that BIN1 loss decreases t-tubule folding, and that a resulting loss of this intra-tubule diffusion barrier promotes arrhythmogenesis.

104. Ge K, DuHadaway J, Du W, Herlyn M, Rodeck U, Prendergast GC. Mechanism for elimination of a tumor suppressor: aberrant splicing of a brain-specific exon causes loss of function of Bin1 in melanoma. Proc Natl Acad Sci U S A. 1999;96(17):9689-94.

105. Fu Y, Hong T. BIN1 regulates dynamic t-tubule membrane. Biochim Biophys Acta. 2016;1863(7 Pt B):1839-47. doi:10. 1016/j.bbamcr.2015.11.004.

106. Fu Y, Shaw SA, Naami R, Vuong CL, Basheer WA, Guo X, et al. Isoproterenol promotes rapid ryanodine receptor movement to bridging integrator 1 (BIN1)-organized dyads. Circulation. 2016;133(4):388-97. doi:10.1161/CIRCULATIONAHA.115. 018535.

107. Laury-Kleintop LD, Mulgrew JR, Heletz I, Nedelcoviciu RA, Chang MY, Harris DM, et al. Cardiac-specific disruption of Bin1 in mice enables a model of stress- and age-associated dilated cardiomyopathy. J Cell Biochem. 2015;116(11):2541-51. doi:10. 1002/jcb.25198.

108. Lyon AR, Nikolaev VO, Miragoli M, Sikkel MB, Paur H, Benard $\mathrm{L}$, et al. Plasticity of surface structures and beta(2)-adrenergic receptor localization in failing ventricular cardiomyocytes during recovery from heart failure. Circulation Heart failure. 2012;5(3): 357-65. doi:10.1161/circheartfailure.111.964692.

109. Hong TT, Smyth JW, Chu KY, Vogan JM, Fong TS, Jensen BC, et al. BIN1 is reduced and Cav1.2 trafficking is impaired in human failing cardiomyocytes. Heart Rhythm. 2012;9(5):812-20. doi:10. 1016/j.hrthm.2011.11.055.

110. Wu CY, Jia Z, Wang W, Ballou LM, Jiang YP, Chen B, et al. $\mathrm{PI} 3 \mathrm{Ks}$ maintain the structural integrity of T-tubules in cardiac myocytes. PLoS One. 2011;6(9):e24404. doi:10.1371/journal. pone.0024404.

111. Al-Qusairi L, Laporte J. T-tubule biogenesis and triad formation in skeletal muscle and implication in human diseases. Skelet Muscle. 2011;1(1):26. doi:10.1186/2044-5040-1-26.

112. Dowling JJ, Vreede AP, Low SE, Gibbs EM, Kuwada JY, Bonnemann CG, et al. Loss of myotubularin function results in T-tubule disorganization in zebrafish and human myotubular myopathy. PLoS Genet. 2009;5(2):e1000372. doi:10.1371/journal. pgen. 1000372.

113. Ibrahim M, Nader A, Yacoub MH, Terracciano C. Manipulation of sarcoplasmic reticulum $\mathrm{Ca}^{2+}$ release in heart failure through mechanical intervention. J Physiol. 2015;593(15):3253-9. doi:10. 1113/jp270446.

114. Huang CK, Chen BY, Guo A, Chen R, Zhu YQ, Kutschke W, et al. Sildenafil ameliorates left ventricular T-tubule remodeling in a pressure overload-induced murine heart failure model. Acta Pharmacol Sin. 2016;37(4):473-82. doi:10.1038/aps.2016.13.

115. Li H, Lichter JG, Seidel T, Tomaselli GF, Bridge JH, Sachse FB. Cardiac resynchronization therapy reduces subcellular heterogeneity of ryanodine receptors, $\mathrm{t}$-tubules, and $\mathrm{Ca}^{2+}$ sparks produced by dyssynchronous heart failure. Circulation Heart failure. 2015;8(6): 1105-14. doi:10.1161/circheartfailure.115.002352.

116. Ibrahim M, Kukadia P, Siedlecka U, Cartledge JE, Navaratnarajah $\mathrm{M}$, Tokar $\mathrm{S}$, et al. Cardiomyocyte $\mathrm{Ca}^{2+}$ handling and structure is regulated by degree and duration of mechanical load variation. $\mathrm{J}$ Cell Mol Med. 2012;16(12):2910-8. doi:10.1111/j.1582-4934. 2012.01611.x.

117. Ibrahim M, Terracciano CM. Reversibility of T-tubule remodelling in heart failure: mechanical load as a dynamic regulator of the Ttubules. Cardiovasc Res. 2013;98(2):225-32. doi:10.1093/cvr/ cvt016.

118. McNary TG, Bridge JH, Sachse FB. Strain transfer in ventricular cardiomyocytes to their transverse tubular system revealed by scanning confocal microscopy. Biophys J. 2011;100(10):L53-5. doi:10.1016/j.bpj.2011.03.046.

119. Dyachenko V, Husse B, Rueckschloss U, Isenberg G. Mechanical deformation of ventricular myocytes modulates both TRPC6 and Kir2.3 channels. Cell Calcium. 2009;45(1):38-54. doi:10.1016/j. ceca.2008.06.003.

120. Crossman DJ, Shen X, Jüllig M, Munro M, Hou Y, Middleditch M, Shrestha D, Li A, Lal S, dos Remedios CG, Baddeley D, Ruygrok PN, Soeller C. Increased collagen within the transverse tubules in human heart failure. Cardiovasc Res. 2017; doi:10. 1093/cvr/cvx055. 